\title{
Principles of Fertilization and Irrigation Management for Vegetables Crops Grown in Florida in the BMP Era: Introduction ${ }^{1}$
}

\section{Eric Simonne and George Hochmuth ${ }^{2}$}

Adequate management of fertilization and irrigation has always been recognized as one of the keys to successful vegetable production in Florida. Thus, fertilization and irrigation practices have aimed at supplying enough nutrients and water to ensure economical yields. As the combined cost of fertilizer and water has traditionally represented approximately only one third of the pre-harvest production costs, fertilizer and water application rates above recommended rates have been considered as an "inexpensive" insurance for high-yielding crops.

With the increase in environmental awareness, fertilizer costs, and competition among water users, the need for higher levels of vegetable crop management has emerged. As water is involved in nitrate and phosphate movement out of the root zone, it is now clear that nutrients and water must to be managed together. The focus of water and nutrient management in the BMP era is now not only to produce vegetables profitability, but also to do so while conserving resources and minimizing the environmental impact of such production.
As the development of Total Maximum Daily Loads (TMDLs) and Best Management Practices (BMPs) for vegetables grown in Florida takes place, growers are eager to find out how this process will affect their operations. TMDLs and BMPs have their origin in Federal and State legislations (Table 1). A TMDL is the maximum amount of a pollutant a water body can receive and still meet its water quality standards. BMPs are specific cultural practices that aim at reducing the load of a specific compound entering a water body, while maintaining economical yields (Table 2). Growers who will have a documented BMP plan will receive a waiver of liability, will be granted a presumption of compliance with water quality standards, and will be eligible for some cost-share programs available to partially refund the cost of BMP implementation.

The BMPs applicable to vegetable production will be included in a new BMP manual for row crops and vegetables, which is currently under development by the Florida Department of Agriculture and Consumer Services (FDACS). Three types of BMPs for vegetable crops are described in this manual: the

1. This document is HS897, one of a series of the Horticultural Sciences Department, Florida Cooperative Extension Service, Institute of Food and Agricultural Sciences, University of Florida. Publication date: January 2003. Please visit the EDIS Web site at http://edis.ifas.ufl.edu.

2. Eric Simonne, assistant professor, George Hochmuth, center director, NFREC-Quincy, Horticultural Sciences Department, Cooperative Extension Service, Institute of Food and Agricultural Sciences, University of Florida, Gainesville, 32611.

The Institute of Food and Agricultural Sciences (IFAS) is an Equal Employment Opportunity - Affirmative Action Employer authorized to provide research, educational information and other services only to individuals and institutions that function without regard to race, creed, color, religion, age, disability, sex, sexual orientation, marital status, national origin, political opinions or affiliations. For information on obtaining other extension publications, contact your county Cooperative Extension Service office. Florida Cooperative Extension Service / Institute of Food and Agricultural Sciences / University of Florida / Larry R. Arrington, Interim Dean 
universal BMPs, the irrigation/engineering BMPs, and the water and nutrient management BMPs. In the BMP Manual for row crops and vegetables, BMPs are 1-to-3 page-long chapters that include a working definition of the topic, list specific things to do (BMPs) as well as things to avoid (pitfalls), and present existing applicable technical criteria together with additional references.

This publication presents a summary of how principles of fertilization and irrigation for vegetable crops should be applied in commercial operations (Table 3). This document is not a substitute for current recommendation (see the Vegetable Production Guide for Florida at http://edis.ifas.ufl.edu/ TOPIC_GUIDE_Vegetable_Production_Guide_for_F lorida) but should be considered an educational tool for the transition period into the BMP era. 
Table 1. A brief legislative history of the Best Management Practices (BMP).

\begin{tabular}{||c|l|l|c||}
\hline \hline Year & \multicolumn{1}{|c|}{ Origin } & \multicolumn{1}{|c||}{ Legislation } & Public Law No. \\
\hline 1948 & $\begin{array}{l}\text { U.S. } \\
\text { Congress }\end{array}$ & Water Pollution Control Act (WPCA) & $80-845$ \\
\hline 1965 & $\begin{array}{l}\text { U.S. } \\
\text { Congress }\end{array}$ & $\begin{array}{l}\text { Amendment to the WPCA created federally approved water } \\
\text { quality standards for interstate waters. Name changed to } \\
\text { Water Quality Act }\end{array}$ & $89-234$ \\
\hline 1972 & $\begin{array}{l}\text { U.S. } \\
\text { Congress }\end{array}$ & $\begin{array}{l}\text { Amendment 303(d) to WQA introduced Total Maximum Daily } \\
\text { Loads (TMDL). Name changed to Federal Water Pollution } \\
\text { Control Act (FWPCA) }\end{array}$ & $92-500$ \\
\hline 1977 & $\begin{array}{l}\text { U.S. } \\
\text { Congress }\end{array}$ & $\begin{array}{l}\text { FWPCA amended to introduce BMP development and } \\
\text { renamed Clean Water Act }\end{array}$ & $95-217$ \\
\hline 1987 & $\begin{array}{l}\text { U.S. } \\
\text { Congress }\end{array}$ & $\begin{array}{l}\text { Amendments 304(1) and 319 introduced the development of } \\
\text { numerical rather than qualitative water quality criteria. New } \\
\text { name: Water Quality Act }\end{array}$ & $100-4$ \\
\hline 1987 & $\begin{array}{l}\text { Florida } \\
\text { Legislature }\end{array}$ & $\begin{array}{l}\text { The Florida Surface Water Improvement and Management } \\
\text { (SWIM) Act created a program which focused on } \\
\text { preservation of the state's water bodies that were in good } \\
\text { condition, and restoration of some of its most significant } \\
\text { water bodies. }\end{array}$ & 373.451 - 373.4595 \\
\hline \hline
\end{tabular}

Table 2. Driving forces behind the vegetable BMPs.

\begin{tabular}{||l|l||}
\hline \hline \multicolumn{1}{|c||}{ BMPs are Meant to Be } & \multicolumn{1}{c||}{ Comments } \\
\hline Educational & $\begin{array}{l}\text { Through teaching and demonstration, the BMP process aims at raising the level of } \\
\text { nutrient and irrigation management by growers. }\end{array}$ \\
\hline Economically sound & BMP implementation is not aimed at reducing production or crop value. \\
\hline Environmentally robust & BMPs are tools to achieve the TMDLs and therefore reduce nutrient discharge. \\
\hline Based on science & Only science-based information will separate fact from perception. \\
\hline \hline
\end{tabular}

Table 3. Principles of nutrient and water management for vegetables in the BMP era.

\begin{tabular}{||c|c|c|c||}
\hline \hline $\begin{array}{c}\text { Management } \\
\text { Area }\end{array}$ & Principle No. & Description & Corresponding Section \\
\hline \hline
\end{tabular}


Table 3. Principles of nutrient and water management for vegetables in the BMP era.

\begin{tabular}{|c|c|c|c|}
\hline \multirow[t]{4}{*}{ Fertilization } & 1 & $\begin{array}{l}\text { With plasticulture, think in terms of } \\
\text { rows and not in terms of field surface } \\
\text { for irrigation and fertilization. }\end{array}$ & - Linear bed feet, HS898 \\
\hline & 2 & $\begin{array}{l}\text { Soil test and follow the } \\
\text { recommendations }\end{array}$ & $\begin{array}{l}\text { - Soil testing, HS900 } \\
\text { - pH management, HS900 } \\
\text { - Fertilization, HS899 } \\
\text { - Macronutrients, HS901 } \\
\text { - Micronutrients, HS901 } \\
\text { - Chemigation and fertigation, } \\
\text { HS902 } \\
\text { - Controlled-Release fertilizer, } \\
\text { HS903 } \\
\text { - Proper use of organic } \\
\text { fertilizers (manure), } \\
\text { HS904 }\end{array}$ \\
\hline & 3 & $\begin{array}{l}\text { Monitor crop nutritional status and } \\
\text { discover how healthy the vegetable } \\
\text { plants are. }\end{array}$ & $\begin{array}{l}\text { - Tissue testing and sap } \\
\text { testing, HS905 } \\
\text { - Supplemental fertilizer } \\
\text { applications, HS906 }\end{array}$ \\
\hline & 4 & $\begin{array}{l}\text { Practice year-round nutrient } \\
\text { management }\end{array}$ & $\begin{array}{l}\text { - Cover crops, HS907 } \\
\text { - Double cropping, HS908 }\end{array}$ \\
\hline \multirow[t]{5}{*}{ Irrigation } & 5 & $\begin{array}{l}\text { Irrigation amount must reflect crop } \\
\text { water use... no more, no less. }\end{array}$ & $\begin{array}{l}\text { - Irrigation scheduling: } \\
\text { Applying the right water } \\
\text { amount and monitoring } \\
\text { soil moisture, HS909 } \\
\text { - Irrigation maintenance and } \\
\text { evaluation, HS910 } \\
\text { - Frost and freeze protection, } \\
\text { HS911 }\end{array}$ \\
\hline & 6 & $\begin{array}{l}\text { Irrigation amount should not exceed } \\
\text { soil water holding capacity. Otherwise, } \\
\text { water is wasted and mobile nutrients } \\
\text { are leached. }\end{array}$ & \\
\hline & 7 & $\begin{array}{l}\text { Rainfall contributes little to } \\
\text { replenishing soil moisture because of } \\
\text { the plastic mulch. }\end{array}$ & \\
\hline & 8 & $\begin{array}{l}\text { Monitor soil moisture level daily and } \\
\text { determine how much water stress the } \\
\text { crop is exposed to. }\end{array}$ & \\
\hline & 9 & $\begin{array}{l}\text { Keep daily fertilizer and irrigation } \\
\text { records. }\end{array}$ & \\
\hline
\end{tabular}

